
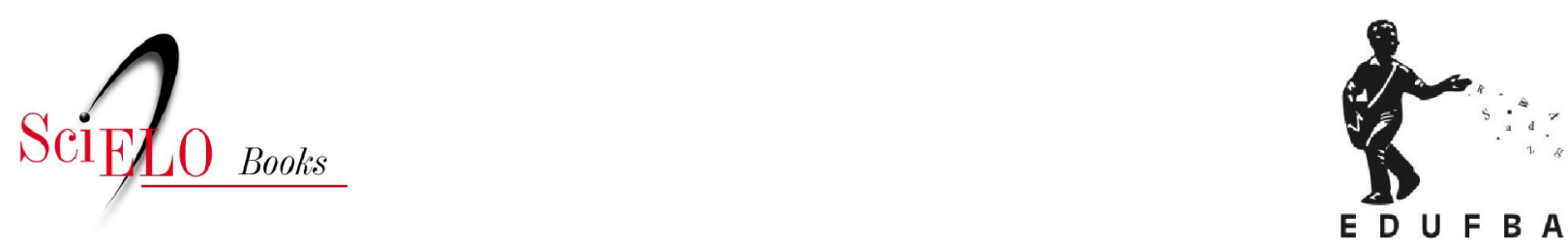

\title{
Parte II: Resistência e legalidade O PCB e os Comitês Populares Democráticos em Salvador (1945- 1947)
}

\author{
Raquel Oliveira Silva
}

SILVA, R.O. O PCB e os Comitês Populares Democráticos em Salvador (1945-1947). In: SENA JÚNIOR, C.Z., ed. Capítulos de história dos comunistas no Brasil [online]. Salvador: EDUFBA, 2016, pp. 175-193. ISBN: 978-85-232-1873-7. https://doi.org/10.7476/9788523218737.0010.

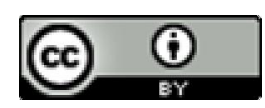

All the contents of this work, except where otherwise noted, is licensed under a Creative Commons Attribution $\underline{4.0 \text { International license. }}$

Todo o conteúdo deste trabalho, exceto quando houver ressalva, é publicado sob a licença Creative Commons Atribição 4.0.

Todo el contenido de esta obra, excepto donde se indique lo contrario, está bajo licencia de la licencia Creative Commons Reconocimento 4.0. 


\title{
O PCB e os Comitês Populares Democráticos em Salvador (1945-1947) ${ }^{1}$
}

\author{
Raquel Oliveira Silva
}

Implantados num contexto de redemocratização, após o fim da ditadura do Estado Novo, e com a legalização do Partido Comunista do Brasil $(\mathrm{PCB})^{2}$ passados 23 anos de clandestinidade, os Comitês Populares Democráticos tinham como objetivo a ligação das massas com os comunistas, por meio da luta por reivindicações imediatas de interesse de melhoria de vida nos bairros e grupos envolvidos. De acordo com Sônia Serra, os Comitês aliavam ao movimento reivindicatório a participação popular em mobilizações "como a luta pela convocação imediata da Constituinte, as manifestações antifascistas e anti-integralistas e especialmente o trabalho de alistamento e esclarecimento eleitoral". ${ }^{3}$ Também chamados de Comissões Populares Democráticas, esses organismos visavam, na linha de ação do PCB, a organização da sociedade civil nos moldes democráticos, além da ampliação das bases do partido, "incorporando às suas fileiras um número cada vez maior de filiados, através de um programa de apoio às

1 O presente texto é resultante da pesquisa de mestrado intitulada O PCB e Comitês Populares Democráticos em Salvador (1945-1947), apresentada ao Programa de Pós-Graduação em História da Universidade Federal da Bahia (PPGH/UFBA) e desenvolvida com o apoio financeiro da Fundação de Amparo à Pesquisa do Estado da Bahia (FAPESB). Este texto é inédito e não se encontra em processo de julgamento em nenhum periódico ou coletânea.

2 O Partido Comunista a que se refere este trabalho denominava-se, durante a década de 1940, Partido Comunista do Brasil (PCB). Mais tarde, passaria a se chamar Partido Comunista Brasileiro, mantendo a sigla PCB. Na década de 1960, o partido sofre uma divisão e surge então a agremiação de linha maoísta, com o título de Partido Comunista do Brasil e a sigla PC do B. SPINDEL, A. O partido comunista na gênese do populismo. São Paulo: Símbolo, 1980. p.17.

3 SERRA, S. O Momento: história de um jornal militante. 1987. 114 f. Dissertação (Mestrado em Ciências Sociais) - Faculdade de Filosofia e Ciências Humanas, Universidade Federal da Bahia, Salvador, 1987. 
reivindicações populares, fora de organismos formais, como o sindicato". ${ }^{4}$ Esperava-se que em cada bairro se formasse um núcleo que reivindicasse as necessidades mais urgentes da população local. Havia Comitês espalhados por todo o Brasil, inclusive na Bahia, abrangendo a capital e os municípios do interior.

Naquela época, o PCB vivia uma fase de prestígio e a anistia geral aos presos políticos do Estado Novo, em abril de 1945, e o novo código eleitoral, de maio, haviam permitido ao Partido Comunista ressurgir como força política. A atmosfera de triunfo sobre o fascismo, no exterior, baseado em uma aliança entre os Estados Unidos e a União Soviética, e da qual o Brasil participara, ajudou a melhorar a reputação do Partido Comunista dentro do país. O partido, portanto, "gozava de prestígio moral de identificação como o povo russo, que havia suportado a agressão nazista na Europa". ${ }^{5} \mathrm{~A}$ nova atmosfera era simbolizada pelo reconhecimento da União Soviética, por parte de Getúlio Vargas, também em abril de 1945.

Com a anistia, Luiz Carlos Prestes, junto com seus companheiros, é posto em liberdade depois de nove anos de prisão. Poucos dias após a anistia, Vargas concede legalidade ao partido, passados vinte e três anos de clandestinidade. Todas essas mudanças proporcionaram o arcabouço legal para a reorganização do PCB. O partido e seus candidatos encontraram ampla receptividade, "especialmente entre os intelectuais e a geração mais jovem que só conhecera a política fechada do Estado Novo". ${ }^{6}$ Os comunistas alcançavam a liderança de muitos sindicatos. Conseguindo uma importante votação nas eleições de 1945, o partido parecia ter assegurada uma base de massas. ${ }^{7}$ Diante disso, os comunistas queriam agora assegurar o seu espaço político legal e, para tanto, jogavam toda a sua capacidade mobilizadora na organização popular e na construção das bases do partido, dirigindo seus esforços maiores a um programa que beneficiava a criação de organismos que agregassem a classe trabalhadora, a exemplo do Movimento Unificador dos Trabalhadores (MUT) e dos Comitês Populares Democráticos. ${ }^{8}$ Esses núcleos podem ser entendidos

4 VAZQUEZ, P. S. Intervalo democrático e sindicalismo: Bahia (1942-1947). 1986. 83 f. Dissertação (Mestrado em Ciências Sociais) - Faculdade de Filosofia e Ciências Humanas, Universidade Federal da Bahia, Salvador, 1986.

5 SKIDMORE, T. Brasil: de Getúlio Vargas a Castelo Branco (1930-1964). Rio de Janeiro: Paz e Terra, 1979. p. 87.

6 Ibid., p. 93.

7 Para a Assembleia Nacional Constituinte, o Partido Comunista do Brasil elegeu quatorze deputados e um senador (Prestes). Na Bahia, para a Câmara Federal, o Partido Comunista elegeu Carlos Marighella, com 5187 votos. SERRA, 1987, p. 56. 
como parte da estratégia comunista de revolução democrática, direcionados não apenas no sentido de mobilização, organização e educação do proletariado, mas também no fortalecimento e ampliação da ligação deste com o Partido Comunista. ${ }^{9}$

O MUT era uma organização intersindical dos trabalhadores que buscava reunir e organizar os dirigentes sindicais e estimular a sindicalização dos trabalhadores, a fim de fortalecer a almejada unidade operária, defendida historicamente pelos comunistas. ${ }^{10}$ Segundo Petilda Vazquez, não era intenção dos comunistas que o MUT fosse um órgão paralelo ao sindicato, mas de sustentação e de propulsão de seu crescimento, atuando na convergência e na unidade dos trabalhadores, uma espécie de Central Sindical Comunista. ${ }^{11}$ Caracterizando-se como um órgão "sem distinção de credos políticos e religiosos”, o MUT, sob a liderança comunista de Manuel Batista de Souza, buscou apoio de setores independentes e do PTB, no auge da campanha anti-integralista, para realização de assembleias e comícios operários. Na prática, o MUT se apresentou como um órgão de fortalecimento dos trabalhadores, ligado ao Partido Comunista. ${ }^{12}$ Defendia a mais ampla sindicalização, salários justos, redução da jornada de trabalho para seis horas, direito de greve e liberdade sindical. ${ }^{13}$

Já os Comitês Populares Democráticos se constituíram em órgãos cuja tarefa principal era organizar o povo, no sentido de desenvolver o trabalho de massas. As Comissões Democráticas foram lançadas em 23 de maio de 1945, quando do grande comício em que Luiz Carlos Prestes falou ao público pela primeira vez, desde a anistia. Os jornais baianos conferiram amplo destaque ao evento, ocorrido no estádio do Vasco da Gama, no Rio de Janeiro. No dia 24 de maio de 1945, o jornal A Tarde enfatizou toda a magnitude do comício, que contou com a presença de milhares de pessoas, incluindo uma entrevista com Rodolfo Ghioldi, líder do Partido Comunista Argentino. ${ }^{14} \mathrm{Na}$ edição desse mesmo dia, sobre esse acontecimento, o jornal O Imparcial publicou uma matéria com a seguinte manchete: “'Hoje,

9 PINHEIRO, M. C. de O. O PCB e os Comitês Populares Democráticos da Cidade do Rio de Janeiro (19451947). 2007. Dissertação (Mestrado em História) - Instituto de História, Universidade Federal do Rio de Janeiro, Rio de Janeiro, 2007.

10 Ibid., p. 115.

11 VAZQUEZ, op. cit., p. 86.

12 VAZQUEZ, 1986, p. 87.

13 TAVARES, L. H. D. História da Bahia. São Paulo: Ática, 1987. p. 441.

14 A TARDE. Salvador, 24 maio 1945. Diário. Biblioteca Pública do Estado da Bahia. Setor: Periódicos Raros. Acervo: Jornais. 
a democracia volta-se para a esquerda', declara Luiz Carlos Prestes” . ${ }^{15}$ A reportagem sugeria a existência de um considerável prestígio dos ideais de esquerda junto à opinião pública, devido à atmosfera de triunfo sobre o fascismo.

O jornal O Imparcial descreveu o comício no estádio do Vasco da Gama como um grande evento, com a presença de mais de noventa mil pessoas, em que o "Cavaleiro da Esperança" afirmou que "dez anos de guerra ao comunismo fizeram do brasileiro o povo mais comunista do mundo". O jornal finaliza informando que, ao fim de seu longo discurso, Prestes "foi ovacionado durante 36 minutos, ininterruptamente”. O jornal Diário da Bahia optou por destacar o apoio dos comunistas à permanência de Vargas na presidência, com a seguinte manchete: "Prestes analisou a situação política do Brasil - reafirmando espírito democrático do pres. Vargas”, ${ }^{16}$ Enumerou alguns trechos do discurso de Prestes, como o que se refere à anistia e à defesa da continuidade de Getúlio na presidência, "para manter a ordem, para levar ao país a eleições livres e honestas e entregar o poder ao eleito da nação”. Já o periódico Estado da Bahia descreveu o ambiente do comício:

[...] de todos os lados viam-se bandeiras brasileiras e das Nações Unidas. Em toda a extensão do gramado a palavra Brasil e como três grandes dados as palavras Fome, Miséria e Fascismo, riscadas por uma cruz. Ao fundo do estádio, o retrato de Prestes, iluminado. ${ }^{17}$

O Estado da Bahia ressaltou a fala do secretário-geral do PCB acerca da colaboração entre os Estados Unidos, a Inglaterra e a União Soviética:

[...] ela [a colaboração] é necessária na paz como foi na guerra, cabendo aos democratas do mundo inteiro apoiar e sustentar a colaboração das três grandes potências, lutando sem repouso pela paz interna da nossa própria Pátria, não poupando esforços para encontrar sempre uma solução pacífica de todas as divergências e contradições que nos possam tentar dividir.

15 O IMPARCIAL,[S. 1.; s.n.], 24 maio 1945. Matutino de propriedade de Franklin Lins de Albuquerque, cujo redator-chefe era o filho do proprietário, Wilson Lins. Biblioteca Pública do Estado da Bahia . Setor: Periódicos Raros. Acervo: Jornais.

16 DIÁRIO DA BAHIA. Salvador: Ed. Diária da Bahia, 1856-1957. Diária. 24 maio 1945. Fundado em 1 janeiro 1856 por Demetrio Ciriaco Tourinho e Manoel Jesuino Ferreira. Biblioteca Pública do Estado da Bahia . Setor: Periódicos Raros. Acervo: Jornais.

17 ESTADO DA BAHIA. [S. 1.], 24 maio 1945. Pertencente à cadeia dos Diários Associados, administrada pelo poeta Odorico Tavares. Biblioteca Pública do Estado da Bahia. Setor: Periódicos Raros. Acervo: Jornais. 
O Estado da Bahia também enfatizou que os comunistas preferiam Vargas no poder, o que é significativo, pois o jornal é assumidamente contrário à permanência do ditador no cargo de mandatário do país. Dentre os jornais da grande imprensa, este último é o único que publicou um trecho no qual Prestes menciona os Comitês Populares Democráticos: "nós, comunistas, não vacilamos [...] Viva a unidade de todo o povo organizado, todos os seus comitês democráticos. Viva a união dos povos amantes da paz e da democracia”.

O jornal O Momento, o jornal vinculado ao PCB e editado em Salvador, atribuiu uma ênfase expressiva à criação dos Comitês Populares Democráticos. Na edição de 04 de junho de 1945, O Momento publicou o trecho do pronunciamento do dia 23 de maio, em que o "Cavaleiro da Esperança" indicou a fórmula a qual, segundo ele, tornaria possível ao povo uma participação realmente efetiva no movimento que asseguraria ao Brasil o caminho pacífico para a democracia, com o fim da ditadura do Estado Novo. Isso seria conseguido através da

[...] organização do povo em amplos comitês nos locais de trabalho, nas ruas e bairros. Comitês Populares Democráticos que, unidos, pouco a pouco, constituirão [...] as organizações democráticas de cada cidade, região ou Estado, até a grande união nacional. ${ }^{18}$

Seguindo esse plano, em junho de 1945, já existiam em Salvador inúmeros Comitês Populares Democráticos, como os dos bairros de Liberdade, Santo Antônio, Pelourinho, Itapagipe, Sete Portas, entre outros. Enquanto organismos que buscariam agregar a população dos bairros pela solução de seus problemas cotidianos, os Comitês Populares Democráticos dispunham de terreno fértil para suas atividades, pois a maior parte da população dos bairros de Salvador vivia em condições difíceis. Se a Bahia dispunha na época de lideranças políticas de prestígio nacional, integrantes dos blocos de poder, uma burguesia comercial e agrária de certo peso, intelectuais de renome, com alguma vida social e cultural, era na verdade em seu conjunto um Estado pobre. ${ }^{19}$ Mesmo na capital, a maioria da população recebia salários muito baixos ou nem regularmente assalariados eram. O povo comia mal, pois a alimentação era cara; morava em

18 O MOMENTO. [S. 1.: s.n.], 4 jun. 1945. Publicação que circulou de 1945 a 1957, apresentando a sua vinculação política e ideológica ao PCB, apesar de inicialmente não ser um órgão oficial do partido. Biblioteca Pública do Estado da Bahia. Setor: Periódicos Raros. Acervo: Jornais. Sobre a história desse periódico, ver a dissertação de SERRA, 1987. 
habitações precárias e insuficientes e se locomovia nos superlotados bondes da americana Companhia Linha Circular.

Para Maria Victoria Espiñeira, embora tenha dado liberdade para a população pobre expressar publicamente os seus problemas, com o fim da ditadura varguista, o pós-guerra vem para agravar esses problemas, "que até então estavam encobertos pela atuação do regime de força do Estado Novo". ${ }^{20}$ Com a finalidade de amenizar todo esse sofrimento, além de rezar, trabalhar e festejar, o povo também lutava. Atendia aos apelos dos comícios, das passeatas, das greves, muitas vezes promovidos pelos comunistas, bem como os do futebol, do carnaval, do candomblé, das missas e festas religiosas, sendo estas manifestações da cultura popular que também contavam com o apoio e o envolvimento dos militantes e simpatizantes do PCB.

Os Comitês Populares Democráticos foram núcleos que visavam organizar a população, atentando para todas essas questões. Em entrevista ao jornal O Imparcial, o comandante Roberto Sisson, ex-dirigente da ANL, discorreu sobre essas comissões. ${ }^{21}$ As declarações de Sisson referem-se, principalmente, à utilidade dos Comitês Populares Democráticos para a preparação e organização de militantes do Partido.

O comandante ressaltou a importância dos Comitês Populares, sobretudo quando urbanos, para a aplicação de teorias sociológicas, possibilitando, dessa maneira, o conhecimento do Brasil: sua geografia, economia, política, seu povo, suas riquezas, bem como suas perspectivas de industrialização. Nesse sentido, os comitês de distritos rurais não deveriam ser esquecidos, para a incorporação das massas do campo "em nossa vida econômica, política e cultural”. Inclusive, esses comitês rurais deveriam merecer uma atenção especial "decorrente de nossa falta de prática no assunto", devendo ser ligados aos comitês urbanos, pois, de acordo com Sisson, não poderia haver solução progressista para os "grandes problemas das nossas cidades sem se resolverem concomitantemente os grandes problemas do campo". Dada a sua experiência na Aliança Nacional Libertadora, o comandante constatou que pequenas dúvidas quanto à organização popular muitas vezes "protelam por muito tempo a concretização de pequenas organizações básicas do povo", daí a necessidade de saber exatamente como instituir um Comitê Popular Democrático.

20 ESPIÑEIRA GONZALEZ, M. V. O Partido, o Estado e a Igreja nas Associações de Bairros de Salvador. Salvador: EDUFBA, 1997. p. 28.

21 O IMPARCIAL. [S. 1.: s.n.], 5 jun.1945. Matutino de propriedade de Franklin Lins de Albuquerque, cujo redator-chefe era o filho do proprietário, Wilson Lins. 
Segundo consta no jornal Tribuna Popular, de modo geral, a criação de um Comitê Popular passava por três fases antes de adquirir, como queriam os comunistas, força e expressão: "fase de organização, fase de direção provisória e fase de estrutura definitiva, com dirigentes democrática e periodicamente eleitos”. ${ }^{22}$ Ainda conforme o periódico, a iniciativa de formar esse organismo, naturalmente, partiria de uma pessoa, mas em breve constituir-se-ia um grupo de interessados que se reuniria na casa de um deles e se transformaria em Comissão Provisória de Organização. Esta dividiria tarefas entre seus membros, visando:

a) Organizar um plano de reivindicações locais realizáveis: melhoria dos transportes, creches, postos médicos, escolas, mercados etc.;

b) Coletar dinheiro;

c) Realizar toda propaganda a seu alcance-pela imprensa, volante, painéis, faixas, inscrições murais etc.-para que, logo na sua formação, o Comitê vá ganhando a indispensável amplitude, tornando-se um organismo não só do grupo que o concebeu, mas de âmbito popular, acessível a todos os que lhe queiram pertencer. $^{23}$

Esse é o período de organização, durante o qual é promovida uma assembleia com a presença e participação ativa do maior número possível de pessoas do bairro ou empresa. Nessa assembleia, entre outros assuntos que pudessem surgir, tratar-se-ia de:

a) Escolher uma direção ainda provisória, a quem cabe desenvolver cada vez mais o Comitê;

b) Discutir um plano de reivindicações realizáveis;

c) Delegar à direção provisória poderes para nomear as várias comissões (de propaganda, de sede definitiva, de fundos, eleitoral, de cultura etc.), que se tornem necessárias ao funcionamento do Comitê. ${ }^{24}$

22 CAVALCANTI, W. Comitês Populares Democráticos (1945), apud Tribuna Popular. Rio de janeiro: [s. n.], 21 jul.1945, apud CARONE, E. O PCB (1943 a 1964). São Paulo: DIFEL, 1982. v. 2, p. 57.

23 Ibid., p. 57.

24 Ibid., p. 58. 
Segundo o militante comunista Pedro Coutinho Filho, "técnico em matéria de comitê", em entrevista ao jornal o Imparcial, "essa direção se processa de maneira verdadeiramente democrática, em moldes inéditos entre nós", na qual não seriam organizadas chapas. Dessa forma, "nada de concreto se decide antes, tudo é debatido, deliberado e organizado pelo próprio povo livremente, na assembléia soberana”. ${ }^{25}$ Depois que o número de associados fosse apreciável, e depois de uma assembleia amplamente anunciada e especialmente convocada, seria feita uma eleição da diretoria definitiva do Comitê Popular Democrático. Ainda no jornal Tribuna Popular, constam as seguintes medidas a serem consideradas entre as atividades dos Comitês:

a) Reivindicações políticas gerais: União Nacional; ordem e tranquilidade; eleições livres e honestas; garantia das liberdades conquistadas, sua ampliação e conquista de novas; reconstitucionalização democrática; direito de voto aos soldados e aos analfabetos etc.;

b) Reivindicações práticas e imediatas para melhoria das condições de vida na população local;

c) Criação de cursos de alfabetização (rápidos, para adultos que queiram se alistar eleitores) e de cultura geral;

d) Criação de um posto de alistamento eleitoral para preparar eleitores independentemente de qualquer interesse ou cor partidária;

e) Mobilização de mulheres visando integrá-las na vida política da nação;

f) Organização de bibliotecas, realização de palestras, conferências etc., visando esclarecer democraticamente o povo;

g) Promover palestras, 'sabatinas' etc., destinadas a esclarecer a legislação eleitoral, principalmente sobre alistamento, maneira de votar, caráter secreto do voto, fiscalização eleitoral etc. ${ }^{26}$

Entre as sugestões gerais, destacam-se: 
a) Não é necessário que os iniciadores de um Comitê sejam membros de tal ou qual partido político. Basta que sejam democratas sinceros;

b) Todas as reivindicações-políticas e econômicas-serão pleiteadas pelo Comitê de maneira pacífica e com vistas ao contínuo fortalecimento, em bases concretas, das ordem [sic] e tranquilidade indispensáveis à marcha para a democracia;

c) O Comitê não tem, por sua própria natureza, qualquer finalidade partidária, nem objetivos filosóficos ou religiosos, aceitando sem distinção de partidos, crenças ou classe a que pertençam, a adesão e o apoio de todos os que desejam bater-se pelas reivindicações populares;

d) As mulheres devem ser especialmente convocadas, no maior número possível, a participarem de todas as atividades do Comitê, inclusive as tarefas relativas à propaganda; novas adesões ao Comitê, alfabetização; coleta de fundos; festividades; levantamento e debate das reivindicações econômicas locais, sobretudo às que se liguem ao nível de vida, que as mulheres, por sua própria condição de donas-de-casa sentem e refletem melhor e mais intensamente. ${ }^{27}$

Adequando-se às resoluções em nível nacional, em 04 de junho de 1945, o PCB baiano reproduziu as orientações para a implantação dos Comitês Populares no jornal $O$ Momento. Em nota no referido periódico, intitulada "Como formar um comitê?", consta que em cada município no interior, em cada bairro na capital, ou em cada fábrica ou local de trabalho numeroso, "por iniciativa do povo se organizará um comitê, uma comissão democrática, núcleo ou que nome tenha". ${ }^{28}$ Assim, à medida que fosse se desenvolvendo, cada organização deveria orientar-se por suas próprias leis, discutidas e aprovadas por suas assembleias, por seus componentes. Os Comitês deveriam ter "sua vida própria, estimular sua iniciativa, desenvolver seu espírito criador". ${ }^{29}$ Percebe-se, então, que era previsto e aceito certo nível de autonomia entre os organismos.

27 CAVALCANTI, apud CARONE, 1982, p. 58-59. 
As Comissões Populares deveriam ainda ser "organismos combativos, cultivar os sentimentos unitários, fundamentar-se em princípios democráticos”. ${ }^{30}$ Tratando-se de um comitê de bairro, sua principal finalidade deveria ser o estudo dos problemas da população local, até encontrar um modo de resolvê-los, reivindicando das autoridades responsáveis melhorias imediatas. No caso das comissões de fábrica, delas poderiam fazer parte não só os operários, como também representantes de patrões progressistas, possibilitando "a solução, em harmonia, das reivindicações dos trabalhadores”. Segundo o texto, eis aí, então, um exemplo de "colaboração de classe”, pois o Comitê Popular de fábrica seria um organismo capaz de, dentro da ordem, possibilitar a solução da reivindicação dos trabalhadores, e como exemplos são citados a elevação dos salários, o aperfeiçoamento da técnica de produção, a elevação do rendimento do trabalho. Dessa maneira, é possível notar que, embora fossem voltados para organizar a classe trabalhadora em prol da reivindicação de suas necessidades mais sentidas, os Comitês Populares também foram idealizados pelos comunistas para se encaixar na linha da União Nacional em torno de uma solução "pacífica" para os problemas nacionais, incluindo a defesa de uma política de "ordem e tranquilidade", visando a consolidação da democracia. Isso é válido tanto para os comitês de fábrica quanto para os de bairro. De fato, em nota publicada no dia 3 de dezembro de 1945, intitulada "O proletariado e a União Nacional”, o jornal O Momento reafirma a ideia de que os organismos ligados ao PCB deveriam avigorar a linha adotada pelo Partido:

[...] a união nacional deve ser reforçada, através das organizações populares, dos comitês democráticos, do Movimento Unificador dos Trabalhadores, das associações de classes, dentro das empresas, através das comissões mistas de empregados e patrões. ${ }^{31}$

Segundo a nota do jornal O Momento publicada a 04 de junho de 1945, reiterando a orientação nacional, os Comitês também iriam se dedicar a outras causas, como o combate ao integralismo e a campanha pelo alistamento eleitoral. Segundo o texto do periódico, separadamente como comissões ou em conjunto como um movimento unificado, nada impedia que esses organismos influíssem diretamente junto aos candidatos das

30 Ibid.

31 (O )PROLETARIADO e a União Nacional. O Momento, [S. 1.], 3 dez. 1945. Publicação que circulou de 1945 a 1957, apresentando a sua vinculação política e ideológica ao PCB, apesar de inicialmente não ser um órgão oficial do partido. Biblioteca Pública do Estado da Bahia. Setor: Periódicos Raros. Acervo: Jornais. 
eleições para a Assembleia Constituinte - a serem realizadas ainda em 1945 - para que incluíssem em suas plataformas "as soluções preferidas pelo povo; ou junto aos governos para que sejam asseguradas condições para eleições livres e honestas”. ${ }^{32}$ Logo, apesar de terem sido idealizados pelos comunistas como organismos sem filiação partidária, objetivos filosóficos ou religiosos, vários manifestos e proclamações dos Comitês Populares implantados, em Salvador, apresentavam em suas pautas o combate ao integralismo e sessões de alistamento eleitoral como prioridades a serem atendidas. É compreensível que os pecebistas procurassem utilizar seus organismos de base, inclusive os Comitês Populares Democráticos, para ampliar sua penetração nas massas, pois se tratava de um contexto em que havia a perspectiva de eleições, levando o Partido a se preocupar com a consolidação de sua legalidade recém-conquistada e com a tentativa de alcançar um resultado expressivo nas urnas.

Na capital baiana, a ideia da fundação dos Comitês Populares Democráticos foi lançada numa reunião na sede da União dos Estudantes da Bahia (UEB), aparentemente em junho de 1945. Levando em consideração que Luiz Carlos Prestes propôs a formação das Comissões Democráticas em seu discurso do dia 23 de maio daquele ano, conclui-se que o CR-BA contava com uma ampla organização, pois foi possível implantar os Comitês em Salvador já no início do mês seguinte. ${ }^{33}$ Segundo o jornal O Momento, a principal finalidade destes organismos era trabalhar pela resolução dos problemas de interesse geral, tais como criação de escolas públicas, melhor iluminação, melhor calçamento, fundação de postos de saúde, saneamento, vigilância contra o "câmbio negro" e a especulação nos preços dos gêneros, bem como todas as demais questões de interesse coletivo surgidas nos bairros. Apesar de serem animadas por comunistas, as Comissões Democráticas Populares foram idealizadas para não terem qualquer finalidade partidária. Entretanto, também deveriam se dedicar a causas mais amplas, exigindo

[...] a cooperação de todos os patriotas e democratas para o esclarecimento público sobre a necessidade de eleições livres e honestas, sobre a importância do voto consciente, combatendo-se deste modo o espírito de fraude e de suborno eleitoral; vigilância

32 O MOMENTO, 4 jun. 1945.

33 É possível deduzir que os Comitês Populares Democráticos foram lançados em Salvador no início de junho, porque a notícia desse lançamento saiu na edição de O Momento do dia 4 de junho de 1945. 
democrática contra a quinta-coluna, particularmente contra os desagregadores integralistas que continuam fiéis ao credo verde. ${ }^{34}$

Quando do lançamento dos Comitês Populares Democráticos em Salvador, vários desses núcleos foram organizados e postos em atividade nos bairros da capital baiana. Diferentemente dos municípios do interior, Salvador não teve apenas um, mas vários Comitês Democráticos espalhados por seu território. Dentre os primeiros a serem implantados, constam os da Estrada da Liberdade, Pelourinho, Baixa dos Sapateiros, Itapagipe, Alto do Peru e Fonte Nova. ${ }^{35}$ Também se constituíram Comissões Populares Democráticas em Santo Antônio, Brotas, Rio Vermelho, Engenho Velho de Brotas, Capelinha, Nazaré, Tororó, Mares, Barbalho, São Caetano, Mont-Serrat, Fazenda Garcia, Cabula, Barris, Garcia, Alto Formoso, Mirante do Campo Santo, São Pedro, Santana e Vasco da Gama. Em 18 de junho de 1945, o jornal O Momento abriu uma seção dedicada ao noticiário das atividades dos Comitês Populares Democráticos da Bahia, além de trazer informações acerca da composição das Comissões e seus manifestos e programas. Assim, através dessa seção, foi possível colher dados para a realização deste estudo.

Foram consultados os planos dos Comitês Populares Democráticos dos bairros de Fonte Nova, Pelourinho, Mares, Alto do Peru e São Caetano. Esses Comitês foram escolhidos devido à disponibilidade de seus programas e dos nomes de seus integrantes, de modo que, através do cruzamento com o levantamento feito pela polícia, fosse possível identificar se existiam pecebistas nas Comissões locais e, consequentemente, verificar o nível de penetração do PCB nesses organismos e se havia influência dos comunistas no teor das reivindicações. Todos os programas têm em comum as exigências por melhoria de vida nos locais de moradia e o combate ao integralismo e à quinta-coluna. Entretanto, há algumas especificidades de bairro para bairro as quais interessa ressaltar.

A Comissão Popular Democrática da Fonte Nova foi fundada na zona de confluência de vários bairros, por moradores da Fonte Nova, Vila América, Sete Portas e arredores, numa reunião realizada na sede do Centro Espírita do Castro Neves. ${ }^{36}$ De acordo com o programa publicado nos jornais

34 ORGANIZAM-SE os Comitês Democráticos Populares. O Momento, [S. 1.], 4 jun.1945. Publicação que circulou de 1945 a 1957, apresentando a sua vinculação política e ideológica ao PCB, apesar de inicialmente não ser um órgão oficial do partido. Biblioteca Pública do Estado da Bahia. Setor: Periódicos Raros. Acervo: Jornais. 
O Momento e O Imparcial, o Comitê Popular da Fonte Nova reivindicava calçamento das ruas, iluminação, conserto dos esgotos e encanamentos, albergue noturno e hospital para pobres, posto de socorro e melhoria das moradias, além de posicionar-se contra a carestia, promover a alfabetização e palestras de interesse geral, trabalhar pela união nacional, combater a quinta-coluna e cooperar com os demais Comitês Populares na adesão à campanha anti-integralista. ${ }^{37}$ Já o Comitê Popular do Alto do Peru foi fundado em 17 de junho de 1945, no distrito de São Caetano. ${ }^{38}$ Seu programa incluía pleitear uma escola pública, criação de bibliotecas populares nos bairros, água canalizada com um chafariz público, posto médico de emergência com seções de assistência pré-natal e infantil, albergue noturno, iluminação pública completa, calçamento das ruas, extinção do "câmbio negro" e o combate ao fascismo e a todas as formas de opressão às liberdades públicas. Dessa maneira, embora se propusessem a cooperar com as demais Comissões e aderir à campanha anti-integralista, os Comitês Populares Democráticos da Fonte Nova e do Alto do Peru apresentaram programas mais voltados ao atendimento das necessidades cotidianas das populações locais.

Já os planos dos Comitês Populares do Pelourinho, dos Mares e de São Caetano, apesar de também incluírem demandas imediatas dos moradores, ressaltam aspectos políticos, como a luta contra o fascismo e a realização de palestras para esclarecimento das massas. ${ }^{39} \mathrm{O}$ Comitê Popular do Pelourinho apresenta, como primeiro item do seu programa, o seu caráter democrático, afirmando estarem "as suas portas abertas às pessoas de ambos os sexos, de qualquer religião, tendências políticas, condições sociais etc.” ${ }^{40}$ Tamanha é a preocupação com o combate a "certas manobras de elementos reacionários e integralistas" que o tema reaparece no segundo item, em que o Comitê do Pelourinho reforça a sua disposição em lutar

37 COMISSÃO Democrática Popular na Fonte Nova. O Imparcial, [S. 1.], 12 jun.1945. Matutino de propriedade de Franklin Lins de Albuquerque, cujo redator-chefe era o filho do proprietário, Wilson Lins. Biblioteca Pública do Estado da Bahia. Setor: Periódicos Raros. Acervo: Jornais. COMISSÃO do Alto do Peru. O Momento, [S. 1.], 9 jul. 1945. Publicação que circulou de 1945 a 1957, apresentando a sua vinculação política e ideológica ao PCB, apesar de inicialmente não ser um órgão oficial do partido. Biblioteca Pública do Estado da Bahia. Setor: Periódicos Raros. Acervo: Jornais.

39 PROGRAMA do Comitê do distrito dos Mares. O Momento, [S. 1.], 25 jun. 1945; REALIZAÇÕES do Comitê do Pelourinho. O Momento, [S. 1.], 2 jul. 1945; MANIFESTO do Comitê Democrático de São Caetano. $O$ Momento, [S. 1.], 16 jul. 1945.

40 COMISSÃO Democrática Popular do Pelourinho - Programa de Reivindicações. O Momento, [S. 1.], 2 jul. 1945. Publicação que circulou de 1945 a 1957, apresentando a sua vinculação política e ideológica ao PCB, apesar de inicialmente não ser um órgão oficial do partido. Biblioteca Pública do Estado da Bahia. Setor: Periódicos Raros. Acervo: Jornais. 
abertamente "contra qualquer forma de fascismo, não subestimando nunca as artimanhas do integralismo, nunca permitindo a sua rearticulação".

O programa da Comissão Popular dos Mares atribuía significativa ênfase à educação política da população local, incluindo entre os seus primeiros itens a realização de palestras sobre temas econômicos, técnicos e políticos, a luta contra todas as formas de fascismo e o estudo dos programas dos partidos políticos, para ver se "realmente resultará para o povo uma situação de melhoria imediata e concreta”. Só então a Comissão dos Mares anunciou que iria priorizar também pelo melhoramento das ruas, internamento dos indigentes, luta contra o "câmbio negro", mas todas essas reivindicações seriam realizadas dentro da lei, certamente para se adequar à linha pela defesa da "ordem e tranquilidade" adotada pelo PCB. Embora, teoricamente, os Comitês Populares não declarassem uma postura política definida, em contrapartida, os organizadores da Comissão de São Caetano parecem ter ignorado esse caráter não partidário que os Comitês Populares Democráticos deveriam assumir, pois encerra o seu programa com as seguintes palavras de ordem:

Viva o Brasil Democrático e Progressista! Viva a gloriosa Força Expedicionária! Guerra implacável à $5^{\mathrm{a}}$ coluna nazi-integralista, trotskistas e reacionários fascistas, inimigos do povo! Viva as Nações Unidas! Viva o grande líder do povo brasileiro - Luiz Carlos Prestes. ${ }^{41}$

Em uma análise simplista, essas sutis diferenças entre as pautas de bairro para bairro poderiam ser atribuídas à maior ou menor presença de comunistas na organização dos Comitês: onde houvesse mais militantes pecebistas, mais forte seria o caráter partidário de seus programas. Porém, as fontes disponíveis não permitiram a confirmação dessa hipótese.

Dentre os Comitês cujos planos foram até agora citados, somente em três deles foi possível confirmar a existência de comunistas em seus cargos: os da Fonte Nova, Alto do Peru e Pelourinho, sendo os dois primeiros, justamente aqueles cujos programas eram mais voltados ao atendimento das necessidades imediatas da população do que ao combate ao integralismo. Dentre os indivíduos apontados como os animadores do Comitê Popular da Fonte Nova, dois foram identificados como comunistas: os estudantes Luiz Contreiras de Almeida e Mário Alves, sendo este último assíduo participante das atividades de vários outros núcleos populares ligados ao PCB. Na Comissão Popular do Alto do Peru, constam em 
sua comissão diretora o estudante Pedro Domiense de Oliveira, apontado pela polícia como ex-aluno do Colégio da Bahia e cobrador do jornal O Momento, e Noemia Domiense Alves, assinalada pela polícia como militante do PCB. ${ }^{42}$ O Comitê Popular do Pelourinho era presidido pelo sapateiro Arlindo Simões, também distinguido pela polícia como militante do Partido Comunista, além de ter contado, na ocasião de sua fundação, com a presença do estudante Walmor Barreto, apontado por João Falcão como membro pecebista. ${ }^{43}$

Foi possível identificar a presença de comunistas em vários outros Comitês Populares Democráticos de Salvador. A Comissão Popular da Estrada da Liberdade contou, em sua formação, com a participação de pelo menos um indivíduo identificado pela polícia como militante da célula da Liberdade, Leocádio Manuel de Jesus. ${ }^{44}$ O Comitê Popular de Nazaré era composto, entre outros, por Abrahim Majdalani, distinguido pela polícia como um "elemento de destaque, figura infalível em todas as manifestações comunistas e membro da direção do Comitê Municipal de Salvador". ${ }^{45}$ Além disso, a Comissão Popular de Nazaré foi presidida por Eusínio Lavigne, advogado e cacauicultor no município de Ilhéus, que viria a ser candidato não-comunista a deputado federal, na chapa do PCB. ${ }^{46}$ Na comissão provisória do Comitê Popular do Barbalho, constam Zitelman de Oliva, apontado por João Falcão como comunista, e Aloísio Gomes dos Santos, o qual a polícia distingue como líder comunista na estiva, fazendo parte da direção do respectivo sindicato. ${ }^{47}$ Fazia parte da direção da Comissão Popular da Estrada do Cabula Antonio Pascazzio Bitencourt, segundo a polícia, "prócer comunista destacado e secretário político do Comitê Estadual da Bahia, do PCB”. ${ }^{48}$ O Comitê Popular dos Barris incluía, na sua comissão de propaganda, o militante Zeid Kertzman, além de ter eleito como seu presidente o dr. Edgar Mata, que viria a ser candidato a deputado pelo PCB. De acordo com relatório da polícia, Mata foi identificado criminalmente como comunista, em 26 de novembro de 1937, além de ser

LEVANTAMENTO parcial do Partido Comunista no Estado da Bahia. APERJ: Fundo DPS. f. 362. CÃO, J. O Brasil e a Segunda Guerra: testemunho e depoimento de um soldado convocado. Brasília: Editora da Universidade de Brasília, 1999. p. 114. 
um orador popular, que tinha tomado parte "em manifestações populares operárias ou simplesmente esquerdistas". ${ }^{49} \mathrm{Em} 27$ de novembro de 1945, o jornal O Momento noticiou que os Comitês Populares de São Pedro e Nazaré enviaram telegrama ao candidato pelo PCB à presidência da República, Yeddo Fiúza, assinado, entre outros, pelo adepto do MUT Celio Guedes, e Dante Buffoni, o qual, embora tenha sido enumerado por João Falcão como um antifascista sem partido, foi descrito pela polícia como um "militante destacado, propagandista vermelho". ${ }^{50}$ O Comitê Popular de Itapagipe foi constituído, entre outros, por Dante Leonelli, apontado por João Falcão como militante do PCB, além de João Martins, assinalado pela polícia como advogado do Partido. ${ }^{51}$

Em 11 de junho de 1945, o Comitê Democrático Popular de Itapagipe realizou um comício no Largo da Boa Viagem, em que falaram alguns indivíduos ligados ao PCB. Segundo consta no jornal O Imparcial, quem iniciou a manifestação, em nome do Comitê Popular local, foi o acadêmico Dante Leonelli, seguido pelo operário Israel Sampaio, representando o proletariado e mostrando o perigo do reaparecimento do integralismo. ${ }^{52}$ Falou também o estudante Mário Alves, em nome da União dos Estudantes da Bahia e das organizações patrióticas. Por fim, discursou o sr. Galindo Júnior, descrito por O Imparcial como um "velho combatente antifascista, que mostrou em palavras claras o valor e a importância das Comissões Democráticas Populares". A manifestação "que, apesar do mau tempo, foi muito concorrida", foi encerrada pelo Sr. Estevão Macedo, convidando o povo para os demais comícios que seriam realizados na península itapagipana. Em relatório produzido pela polícia, Macedo é assinalado como dirigente do PCB, além de ser descrito como "prócer comunista exaltado e persistente", "orador constante em comícios populares notadamente entre o pessoal de fábricas". ${ }^{53}$ Justamente por conta de seu hábito de falar em público, Estevão respondeu a um processo a partir de abril de 1946 por haver dito, num comício, "que o atual ministro da Guerra leva a vida bebendo cachaça". ${ }^{4}$

49 LEVANTAMENTO parcial do Partido Comunista no Estado da Bahia. APERJ: Fundo DPS. f. 358.

50 Informações sobre Dante Buffoni em FALCÃO, 1999, p. 114; e em LEVANTAMENTO..., op. cit., f. 361.

51 Dados sobre Dante Leonelli em FALCÃO, op. cit., p. 114; sobre João Martins, em LEVANTAMENTO..., op. cit., f. 361.

52 O IMPARCIAL. [S. 1.: s.n.], 12 jun. 1945

53 LEVANTAMENTO..., op. cit., f. 359.

54 Ibid., f. 359. 
Houve Comitês Populares em que não foi possível identificar se existia relação entre suas lideranças e o Partido Comunista, mas isso não descarta a possibilidade de realmente ter ocorrido entre esses mesmos líderes o intercâmbio Comitês-PCB. Em contrapartida, através dos exemplos acima, pode-se concluir que, de modo geral, é significativa a presença de comunistas atuando na organização e na realização das atividades dessas Comissões. Nas fontes consultadas, pelo menos um membro de cerca de $40 \%$ dos Comitês Populares implantados em Salvador tinha algum nível de envolvimento com o Partido. Como as Comissões Populares Democráticas se propunham a organizar o povo e a combater o integralismo, não é descabido pressupor que houvesse comunistas em seus cargos, bem como democratas e antifascistas em geral, mas é instigante questionar até que ponto os pecebistas influenciavam na administração e no funcionamento dos Comitês, levando em consideração que esses organismos se declaravam independentes de filiações partidárias.

De acordo com o depoimento do ex-militante do PCB, Luiz Contreiras de Almeida, que participou da formação do Comitê Popular da Fonte Nova e das atividades do Comitê Popular de Brotas, compunham esses organismos comunistas e não comunistas, sobretudo os moradores, "pessoas, assim, que queriam discutir os problemas do bairro". ${ }^{55}$ Geralmente, a iniciativa de fundar uma Comissão Democrática Popular partia de algum militante do PCB, que arregimentava pessoas interessadas na ideia. Dessa forma, "os comunistas convocavam pessoas que não eram comunistas, mas que eram assim, amigos, simpatizantes, para reunir nesses comitês, entendeu? Então, semanalmente ou quinzenalmente a gente se reunia. Se reunia e discutia." Segundo o depoente, a receptividade dos moradores dos bairros era razoável. O Comitê Popular de Brotas, especificamente, chegava a reunir em torno de vinte a trinta pessoas, que se encontravam na sede situada numa sala alugada, no intuito de discutir "questão do transporte, questão da carestia, se discutia muito também. Questão de escola para os bairros. Esses problemas mais ligados ao interesse de cada bairro". Finalizando, Contreiras contribui com mais uma informação relevante para avaliar o nível de participação dos comunistas nos Comitês Populares Democráticos, ao atribuir o fim desses organismos à cassação do registro do PCB, em 1947, pois "os comunistas eram os que frequentavam mais firmes, mais assíduos, compreendeu? Os que tinham mais responsabilidade pela manutenção do comitê". 
Segundo Maria Victoria Espiñeira, a estratégia do Partido Comunista era a de não expor sua participação nos movimentos populares. ${ }^{56}$ Todavia, o testemunho de Luiz Contreiras reitera o que já podia ser inferido através de uma análise das fontes até o momento apresentadas neste trabalho. Embora não seja possível identificar uma vinculação de todos os membros de Comissões Populares Democráticas ao PCB, é perceptível que os comunistas tinham uma considerável penetração nesses organismos e eram, em grande parte, responsáveis pelo seu funcionamento. A diversidade de pessoas que compunham os Comitês Populares provavelmente resultou na variação entre os programas produzidos pelo organismo de cada bairro, mas ainda assim a diferença entre esses planos era muito sutil. As Comissões Populares Democráticas tinham, basicamente, as mesmas características e normas, enquadrando-se no padrão sugerido pelos comunistas que, por meio da imprensa, divulgaram as instruções de como formar Comitês, como já foi apresentado neste trabalho, em edições dos jornais Tribuna Popular, O Momento e O Imparcial.

Os Comitês Populares Democráticos deveriam seguir o modelo elaborado pelos comunistas, que acompanhavam detidamente o desenvolvimento desses núcleos nos bairros e, inclusive, promoviam atividades conjuntas das Comissões de vários lugares de Salvador. Eram frequentes os eventos organizados por determinado Comitê que contavam com a presença de representantes de outros lugares, como o comício anti-integralista do Comitê Popular Democrático de Brotas, o qual incluiu a participação de membros das diversas comissões de bairros da cidade. ${ }^{57} \mathrm{O}$ primeiro comício do Comitê Popular do Engenho Velho contou com discursos de membros dos Comitês de Brotas, Pelourinho e Cabula, e com a presença do dirigente sindical Juvenal Souto. ${ }^{58}$ Logo, havia um intercâmbio entre os organismos dos vários locais de Salvador, o que sugere que as ações dos Comitês ocorriam em unidade e de maneira coordenada, muito possivelmente pela própria agremiação comunista.

Além disso, representantes dos Comitês Populares participavam de atividades do PCB, como a sessão pública de instalação da sede do Comitê Estadual do Partido, em julho de $1945 .{ }^{59}$ Ainda nesse mesmo mês, no Teatro Jandaia, as Comissões Populares conduziram cartazes e dísticos,

56 ESPIÑEIRA-GONZALEZ, 1997, p. 30.

57 REALIZAÇÕES do Comitê de Brotas. O Momento, [S. 1.], 23 jul. 1945.

58 COMISSÃO Popular Democrática do Engenho Velho. O Momento, [S. 1.], 6 ago. 1945.

59 FALCÃO, J. O Partido Comunista que eu conheci: 20 anos de clandestinidade. Salvador: Contexto e Arte, 2000. 
com palavras de ordem do Partido, no comício em homenagem a Pablo Neruda, então em visita à capital baiana. ${ }^{60}$ Os Comitês Populares Democráticos também enviaram telegramas e se empenharam na organização de comícios de apoio ao candidato pelo PCB à presidência da República, Yeddo Fiúza. ${ }^{61}$ Depreende-se disso que, por mais que fossem idealizados para serem organismos com autonomia para preparar seus próprios estatutos e realizar suas próprias atividades, na prática, os Comitês Populares Democráticos funcionaram como órgãos auxiliares do PCB para atuar junto à população dos bairros, visando uma maior penetração do Partido nas massas, fora dos espaços sindicais.

60 REALIZOU-SE, ontem, o Comício Pablo Neruda. Estado da Bahia, [S. 1.], 31 jul. 1945.

61 O MOMENTO. [S. 1.: s.n.], 27 nov. 1945. 